\title{
THE INFLUENCE OF DIFFERENT TORQUE SETTINGS ON THE AMOUNT OF APICALLY EXTRUDED DEBRIS DURING ROTARY INSTRUMENTATION
}

\section{ABSTRACT}

Objectives: This in vitro study was designed to evaluate the effect of lowand high-torque settings on the amount of apically extruded debris during canal preparation with the ProTaper Universal (PTU) system.

Materials and Methods: Forty extracted mandibular premolars were selected and randomly divided into two groups $(n=20)$. Each root canal was prepared according to the manufacturer's instructions, using SX, S1, S2, F1, F2, and F3 at low-torque settings and high-torque settings. The apically extruded debris was collected into preweighed Eppendorf tubes. The weight of extruded debris was determined, and data were analyzed using the MannWhitney $U$ test at a significance level of $\mathrm{p}<0.05$.

Results: No significant difference was observed between the groups ( $>0.05)$. The PTU system produced the higher mean extrusion value at hightorque settings.

Conclusions: Under the conditions of this study, as no difference among the different torque settings in terms of the amount of extruded debris were noted, it is possible to suggest that clinicians should choose the most appropriate settings for each case in clinical practice.

Keywords: Endodontics, root canal preparation, torque.
*Demet Altunbaş ${ }^{1}$

Mustafa Toyoğlu

ORCID IDs of the authors:

D. A. 0000-0002-7532-4785

M. T. 0000-0003-1248-6450
Received : $: 21.02 .2020$

Accepted : 14.07 .2020

How to Cite: Altunbaş D, Toyoğlu M. The Influence of Different Torque Settings on the Amount of Apically Extruded Debris During Rotary Instrumentation. Cumhuriyet Dent J 2020;23:3:160-166.

*Corresponding Author:

Department of Endodontics, Faculty of Dentistry, Sivas Cumhuriyet University, Sivas, Turkey

Phone: +90 34621910 10-2764 Fax: +90 3462191237 E-mail: dt_demmet@hotmail.com 


\section{INTRODUCTION}

Dentin chips, pulp tissue, microorganisms, and irrigants may be extruded into the periapical tissues during root canal instrumentation. The apical extrusion may cause periapical inflammation and postoperative pain. ${ }^{1,2}$ Several factors, such as type of the file, instrumentation technique and kinematic, apical preparation size, end-point of the instrumentation, canal or apical foramen size, canal curvature, irrigation solutions and techniques, and type of needle tip that may affect the amount of apically extruded intracanal materials, have been investigated in many studies which have shown that all conditions result in apical extrusion. ${ }^{3-10}$ However, the amount of debris and irrigant extruded apically may differ according to these factors, and minimizing the apical extrusion can reduce the incidence of postoperative pain.

Torque is another changeable parameter during the instrumentation of root canals with rotary nickel-titanium (NiTi) instruments and is especially important to reduce the incidence of instrument locking, deformation, and separation. High torque may cause the instrument to lock and, consequently, cause deformation and separation. ${ }^{11}$ Different torque settings are recommended for different type and size instruments by the manufacturers because each instrument has a specific ideal torque. Low-torque values are usually recommended for the smallest and less tapered instruments, but the largest and more tapered ones can be used with high-torque values. Theoretically, the instrument becomes more active when used with high-torque values. However, the cutting efficiency of the instrument would be reduced with low-torque, and progression of the instrument in the canal would be more difficult. ${ }^{12}$

Several studies have investigated debris extrusion with different NiTi file systems. ${ }^{13-16}$ The ProTaper Universal (PTU; Dentsply Maillefer, Ballaigues, Switzerland) is one of the most widely used rotary systems, and it is characterized by its convex, triangular cross-sectional design, positive rake angle, and progressive taper. Some studies have shown that instrumentation with the PTU system resulted in significantly more debris extrusion than with other NiTi file systems. ${ }^{14,16,17}$ These file systems can be used in a wide range of torque settings during instrumentation, according to the manufacturer. ${ }^{18,19}$ To the best of our knowledge, no published studies have investigated the effect of different torque settings on apical extrusion of debris after root canal preparation using PTU system. Therefore, the purpose of the present study was to compare the amount of debris extruded apically after instrumentation of root canals using the PTU system at low- or hightorque settings. The null hypothesis tested was that there is no significant difference between the low- and high-torque settings groups in terms of apically extruded debris.

\section{MATERIALS AND METHODS}

The research design was approved by the Clinical Research Ethics Committee of Sivas Cumhuriyet University in Sivas, Turkey (2016-01/07). Extracted, straight, single-rooted human mandibular premolars with a single canal were used. Roots with resorption, fractures, or open apices were excluded. The radiographs from the buccolingual and mesiodistal angles were taken to evaluate the root canal anatomy. Soft tissue and calculus were removed from the external root surfaces with hand instrumentation, and all teeth were stored in sterile saline until used. The teeth were decoronated with a diamond disc to obtain $17 \mathrm{~mm}$ root canal length. Apical patency was assessed with a size 10 K-file (Dentsply Maillefer). Working length for each canal was established by subtracting $1 \mathrm{~mm}$ from the length where a size $10 \mathrm{~K}$-file was visible at the major foramen. Teeth in which a size $15 \mathrm{~K}$-file (Dentsply Maillefer) did not easily access the working length and did not extrude beyond the minor foramen were included in the study. 2 groups of 20 teeth each were finally formed in order to have 0.80 power ( 1 - beta), beta of 0.20 , and an alpha error probability of 0.05 . The selected teeth, according to these criteria, were randomly distributed into low- and high- torque setting groups by flipping of a coin.

The experimental model, similar to that described in a study ${ }^{20}$, was used to evaluate debris extrusion. The covers of the Eppendorf tubes were 
separated, and an electronic balance (Precisa XB 220A; Precisa Inst., Dietikon, Switzerland), having an accuracy of $0.0001 \mathrm{~g}$, was used to measure the weights of the empty tubes. Three successive measurements were obtained for each tube, and the average value was recorded. Holes were created on the covers of the Eppendorf tubes, and each root was fixed through the cover by using hand pressure. A 27-gauge needle was inserted into the cover to balance the internal and external pressures, and then each cover with the root and needle was attached to the tubes. The tubes were placed into vials, which were coated with an aluminum foil to avert the operator from seeing extrusion.

In all groups, instrumentation was performed with the PTU system by using a torque-controlled electric motor (X-Smart; Dentsply, Maillefer) at $300 \mathrm{rpm}$. The lowest and highest torque values for each instrument (Table 1), determined according to the manufacturer's recommendation, were used for the root canal preparations. ${ }^{18}$

Table 1. Lowest and highest torque settings recommended by the manufacturer for each ProTaper Universal file

\begin{tabular}{ccccccc}
\hline & SX & S1 & S2 & F1 & F2 & F3 \\
\hline Lowest torque settings $(\mathbf{N c m})$ & 3 & 2 & 1 & 1.5 & 2 & 2 \\
Highest torque settings $(\mathbf{N c m})$ & 4 & 3 & 1.5 & 2 & 3 & 3 \\
\hline
\end{tabular}

However, the $1.5 \mathrm{Ncm}$ torque proposed by the manufacturer for the F1 and S2 instruments was not included in the settings of the X-Smart motor. Therefore, torque was adjusted to $1.6 \mathrm{Ncm}$ (to avoid falling below the recommended minimum torque value of $\mathrm{F} 1$ instrument) for the $\mathrm{F}$ 1 instrument in the low-torque group and to 1.4 $\mathrm{Ncm}$ (to avoid exceeding the recommended maximum torque value of S2 instrument) for the S2 instrument in the high-torque group. The instrumentation sequence was SX (2/3 of the working length), S1-2 (full working length), and F1-3 (full working length). After the use of each instrument, apical patency was confirmed to avoid an apical blockage. Instruments were used to prepare only four canals. A single operator performed all instrumentation to avoid variation and eliminate bias. The root canals were irrigated using a VATEA peristaltic pump (ReDent-Nova, Ra'anana, Israel) to obtain a $2 \mathrm{~mL} / \mathrm{min}$ flow rate of the irrigation solution. After each instrument change, $2 \mathrm{~mL}$ of bidistilled water were used as an irrigant, and each canal was irrigated with a total volume of $13 \mathrm{~mL}$ irrigant during preparation.

After the preparation was performed, the roots were washed with $1 \mathrm{~mL}$ of bidistilled water into the tubes to collect the debris adherent to the root surface. The tubes were placed in an incubator at $37^{\circ} \mathrm{C}$ for 15 days for irrigant evaporation before weighing the tubes which included the dry debris. The weight of each tube was measured three times consecutively, and the average value was recorded. The weight of extruded debris was calculated by subtracting the weight of the empty tube from the final weight. All the initial and final weights of the eppendorf tubes were measured by a second operator.

Statistical analysis was performed with IBM SPSS Statistics version 22.0 (IBM SPSS Statistics, Inc., Armonk, NY, USA). The normality of the data was assessed by the Kolmogorov-Smirnov test and the amount of extruded debris was analyzed statistically by using the Mann-Whitney $U$ test. The level of significance was set at $\mathrm{p}<0.05$.

\section{RESULTS}

Debris extrusion was recorded in both groups. The mean values and standard deviations of the amount of apically extruded debris are shown in Figure 1. The quantity of debris extrusion was $0.00027 \pm 0.000156 \mathrm{~g}$ for the high-torque group and $0.00022 \pm 0.000144 \mathrm{~g}$ for the low-torque group. The mean debris extrusion value of the PTU instruments in the high-torque group was higher than in the low-torque group, but no significant difference was found between the groups ( $\mathrm{p}=0.227)$. 


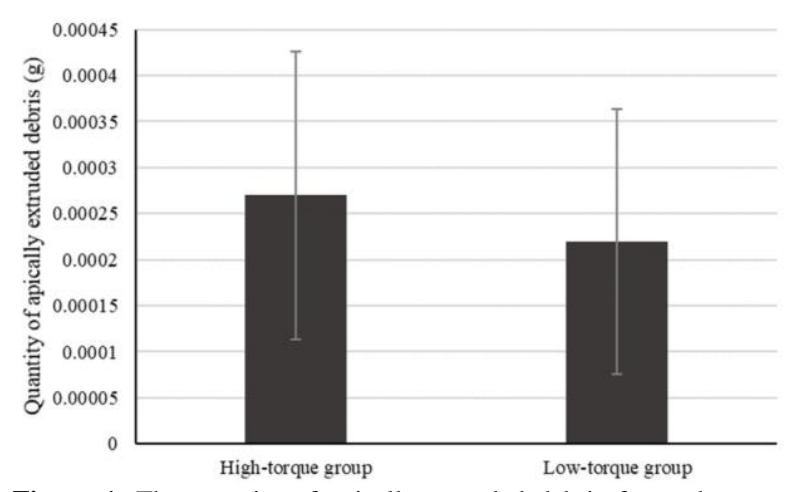

Figure 1. The quantity of apically extruded debris for each group (error bars correspond to the standard deviation). Statistically no significant difference between the groups was observed $(\mathrm{p}=0.227)$.

\section{DISCUSSION}

Fracture of rotary instruments can occur due to flexural or torsional fatigue. ${ }^{21}$ Fracture caused by torsional fatigue occurs when the tip, or any other part of the file is locked in the canal while the shaft continues to rotate. ${ }^{22}$ To prevent this type failure, different torque settings are recommended for each instrument by the manufacturers. Although torque has an influence on the cutting efficiency and instrument progression in the canal, studies have usually investigated the effect of torque settings on the failure of rotary $\mathrm{NiTi}$ instruments. ${ }^{23-25}$ The effect of torque settings on the crack formation in root dentin ${ }^{26,27}$ and the cleaning efficiency of the rotary instruments ${ }^{28}$ have also been investigated in some studies. To our knowledge, the influence of different torque settings on the apical extrusion of debris occurring after canal instrumentation with PTU system have not been tested and reported in the literature. In the present study, the amount of debris extruded apically after instrumentation of root canals using the PTU system at low- or high-torque settings was evaluated and the difference between the groups was not statistically significant. Therefore, the null hypothesis was accepted.

Many studies have shown that the PTU system is associated with more debris extrusion than other NiTi file systems, and according to these previous studies, larger apical tapers of the PTU instruments (F1: 7\%, F2: 8\%, and F3: 9\%) may result in more aggressive preparation of the root canals, which might explain the increased debris production and extrusion with this system. ${ }^{16,17,29}$ Therefore, in the present study, the effects of low- and high-torque settings of the
PTU system on the amount of apically extruded debris were evaluated and apical debris extrusion occurred during canal instrumentation with PTU regardless of the different torque settings that were used. Although there was no significant difference among the low- and high-torque settings, when the average debris extrusion values of the different torque settings were examined, high-torque settings resulted in more debris extrusion than low-torque settings. The cutting ability increases with high-torque settings ${ }^{12}$, and the greater debris extrusion in the high-torque group may be related to increased cutting efficiency and debris production. In addition, the operator noticed that the screw-in tendency of the PTU files increased at high torque settings. The strong screw-in tendency may cause unwanted penetration of the instrument beyond the apical foramen and torsional stress increase at the moment of screw-in. ${ }^{30,31}$ The motor starts to rotate counter-clockwise at low-torque settings when these stresses increase. This action may reduce transportation of debris toward the apex by preventing over-instrumentation risk due to the screw-in tendency of the instruments.

In order to avoid variation and eliminate bias during the assessment of apically extruded debris, standardization of the methodology used is necessary. In the present study, teeth were selected taking into account their type, number of canals, curvature and the initial foramen diameter. Working lengths of the samples was standardized. All instrumentation and irrigation procedures were performed by a single operator to reduce operator variability and a second operator who was blinded to the group assignment performed all the initial and final measurements of the Eppendorf tubes. Bidistilled water was used for the irrigation of root canal to avoid potentially misleading results from the crystallization of sodium hypochlorite. ${ }^{32}$ The method proposed by Myers and Montgomery ${ }^{20}$ was used to evaluate debris extrusion. This testing model did not include a material such as floral foam in the simulation of the resistance of periapical tissues. The usage of floral foam may affect the results due to absorption of some debris and irrigant 
when used as a physical barrier. For this reason, no attempt was made to simulate periapical resistance in this study. Thus, the results cannot be directly extrapolated to the clinical environment. It has also been reported that, the differences in dentin microhardness of human teeth used might affect the results of the studies. In teeth with lower hardness, residues may be more easily extruded into the periapical tissues. ${ }^{33}$

\section{CONCLUSIONS}

Under the conditions of this study, the PTU system was associated with apical debris extrusion at both torque settings and as no differences among the different torque settings were noted, it is possible to suggest that clinicians should choose the most appropriate settings for each case in clinical practice.

\section{ACKNOWLEDGMENT}

This research was presented as an oral presentation at the $23^{\text {th }}$ İzmir Chamber of Dentists International Scientific Congress and Exhibition, İzmir, Turkey, Nov 18-20, 2016.

\section{CONFLICTS OF INTEREST STATEMENT}

The authors declare that there is no competing interest.

\section{Farklı Tork Ayarlarının Rotary Enstrümantasyon}

\section{Strasında Apikalden Taşan Debris Miktarına Etkisi}

\section{$\ddot{O} Z$}

Amaç: Bu in vitro çallşma, ProTaper Universal (PTU) sistemle kök kanal preparasyonu sırasında düşük ve yüksek tork ayarlarının apikalden taşan debris miktarına etkilerini değerlendirmek için planland. Gereç ve Yöntemler: 40 adet çekilmiş mandibular premolar diş seçildi ve rastgele iki gruba ayrıldı (n=20). Her bir kök kanalı üreticinin önerilerine göre düşük ve yüksek tork ayarlarında $S X, S 1, S 2, F 1, F 2$ ve F3 kullanilarak prepare edildi. Apikalden taşan debris önceden tartılmış Eppendorf tüplerine toplandı. Taşan debris ăgırliğ belirlendi ve veriler Mann-Whitney $U$ testi kullanılarak 0,05 anlamlılık düzeyinde analiz edildi. Bulgular: Gruplar arasinda anlaml fark gözlenmedi $(p>0,05)$. PTU sistem yüksek tork ayarlarında daha yüksek ortalama ekstrüzyon değeri ortaya koydu. Sonuç: Bu çalışmanın koşulları altında, farklı tork ayarları arasında taşan debris miktarı yönünden herhangi bir fark olmadı̆̆ $i$ için, klinisyenlerin klinik uygulamada her vaka için en uygun ayarlart seçmeleri gerektiğini önermek mümkündür. Anahtar Kelimeler: Endodonti, kök kanal preparasyonu, tork.

\section{REFERENCES}

1. Seltzer S, Naidorf IJ. Flare-ups in endodontics: I. Etiological factors. J Endod 1985;11:472-478.

2. Siqueira JF, Jr, Rocas IN, Favieri A, Machado AG, Gahyva SM, Oliveira JC, Abad EC. Incidence of postoperative pain after intracanal procedures based on an antimicrobial strategy. J Endod 2002;28:457-460.

3. Karatas E, Ozsu D, Arslan H, Erdogan AS. Comparison of the effect of nonactivated self-adjusting file system, Vibringe, EndoVac, ultrasonic and needle irrigation on apical extrusion of debris. Int Endod J 2015;48:317-322.

4. Silva EJ, Teixeira JM, Kudsi N, Sassone LM, Krebs RL, Coutinho-Filho TS. Influence of Apical Preparation Size and Working Length on Debris Extrusion. Braz Dent J 2016;27:28-31.

5. Gunes B, Yeter KY. The effect of cervical preflaring on the apical debris extrusion of single or multiple rotary Ni-Ti files. Niger J Clin Pract 2020;23:510-514.

6. Karataslioglu E, Arslan H, Er G, Avci E. Influence of canal curvature on the amount of apically extruded debris determined by using three-dimensional determination method. Aust Endod J 2019;45:216-224.

7. Barbosa-Ribeiro M, Arruda-Vasconcelos R, Fabretti FL, Silva E, De-Deus G, Gomes B. Evaluation of Apically Extruded Debris Using Positive and Negative Pressure Irrigation Systems in Association with Different Irrigants. Braz Dent J 2018;29:184-188.

8. Toyoglu M, Altunbas D. Influence of Different Kinematics on Apical Extrusion of Irrigant and Debris during Canal Preparation Using K3XF Instruments. J Endod 2017;43:1565-1568.

9. Türker SA, Koçak S, Kocak M, Saglam B. Effect of glide path preparation on apical debris extrusion of rotary and reciprocating single-file systems: OneShape versus WaveOne. Cumhuriyet Dent J 2015;18:1-8.

10. Keleş A, Özyürek EU, Uysal S, Tuncel B, Uyanik Ö, Nagaş E. Comparison of Apically Extruded Debris 
Associated with Different Nickel-Titanium Systems. Cumhuriyet Dent J 2019;22:192-197.

11. Yared GM, Dagher FE, Machtou P, Kulkarni GK. Influence of rotational speed, torque and operator proficiency on failure of Greater Taper files. Int Endod J 2002;35:7-12.

12. Gambarini G. Advantages and disadvantages of new torque-controlled endodontic motors and lowtorque NiTi rotary instrumentation. Aust Endod J 2001;27:99-104.

13. Kirchhoff AL, Fariniuk LF, Mello I. Apical extrusion of debris in flat-oval root canals after using different instrumentation systems. J Endod 2015;41:237-241.

14. Cakici F, Cakici EB, Kucukekenci FF, Uygun AD, Arslan H. Apically extruded debris during root canal preparation using ProTaper Gold, ProTaper Universal, ProTaper Next, and RECIPROC instruments. Int J Artif Organs 2016;39:128-131.

15. Farmakis ET, Sotiropoulos GG, Abramovitz I, Solomonov M. Apical debris extrusion associated with oval shaped canals: a comparative study of WaveOne vs Self-Adjusting File. Clin Oral Investig 2016;20:2131-2138.

16. Silva EJ, Carapia MF, Lopes RM, Belladonna FG, Senna PM, Souza EM, De-Deus G. Comparison of apically extruded debris after large apical preparations by full-sequence rotary and single-file reciprocating systems. Int Endod J 2016;49:700-705.

17. Ozsu D, Karatas E, Arslan H, Topcu MC. Quantitative evaluation of apically extruded debris during root canal instrumentation with ProTaper Universal, ProTaper Next, WaveOne, and selfadjusting file systems. Eur J Dent 2014;8:504-508.

18. X-Smart Torque Card. Available at: http://www.dentsply.com/content/dam/dentsply/pim/m anufacturer/Endodontics/Motors__Apex_Locators/Mot ors/X_Smart_Endodontic_Rotary_Motor/X-SmartEndodontic-Rotary-Motor-5yqat7i-en-1402. Accessed February 11, 2020.

19. ProTaper Universal Guidelines and Pack Details. Available at: https://e-ecodent.gr/images/ProductsInfo/ MAILLEFER/sequence.pdf. Accessed February 11, 2020 .
20. Myers GL, Montgomery S. A comparison of weights of debris extruded apically by conventional filing and Canal Master techniques. J Endod 1991;17:275-279.

21. Sattapan B, Nervo GJ, Palamara JE, Messer HH. Defects in rotary nickel-titanium files after clinical use. J Endod 2000;26:161-165.

22. Topcuoglu HS, Topcuoglu G, Akti A. Comparative evaluation of cyclic fatigue resistance of D-RaCe and ProTaper retreatment instruments in curved artificial canals. Int Endod J 2016;49:604-609.

23. Berutti E, Negro AR, Lendini M, Pasqualini D. Influence of manual preflaring and torque on the failure rate of ProTaper rotary instruments. J Endod 2004;30:228-230.

24. Di Nardo D, Seracchiani M, Mazzoni A, Del Giudice A, Gambarini G, Testarelli L. Torque Range, a New Parameter to Evaluate New and Used Instrument Safety. Applied Sciences 2020;10:3418.

25. Alqedairi A, Alfawaz H, Abualjadayel B, Alanazi M, Alkhalifah A, Jamleh A. Torsional resistance of three ProTaper rotary systems. BMC oral health 2019;19:124.

26. Dane A, Capar ID, Arslan H, Akcay M, Uysal B. Effect of Different Torque Settings on Crack Formation in Root Dentin. J Endod 2016;42:304-306.

27. Mousavi E, Movahedi SM. The Effects of Different Torques on Dentinal Crack Formation in Root Canals Using the Race Rotary System. Annals of Dental Specialty 2018;6:182-186.

28. Suffridge CB, Hartwell GR, Walker TL. Cleaning efficiency of nickel-titanium GT and .04 rotary files when used in a torque-controlled rotary handpiece. $\mathrm{J}$ Endod 2003;29:346-348.

29. Kustarci A, Akdemir N, Siso SH, Altunbas D. Apical extrusion of intracanal debris using two engine driven and step-back instrumentation techniques: an invitro study. Eur J Dent 2008;2:233-239.

30. Ha JH, Park SS. Influence of glide path on the screw-in effect and torque of nickel-titanium rotary files in simulated resin root canals. Restor Dent Endod 2012;37:215-219. 
31. Ha JH, Cheung GS, Versluis A, Lee CJ, Kwak SW, Kim HC. 'Screw-in' tendency of rotary nickel-titanium files due to design geometry. Int Endod J 2015;48:666672.

32. Sen OG, Bilgin B, Kocak S, Saglam BC, Kocak MM. Evaluation of Apically Extruded Debris Using
Continuous Rotation, Reciprocation, or Adaptive Motion. Braz Dent J 2018;29:245-248.

33. Tanalp J, Gungor T. Apical extrusion of debris: a literature review of an inherent occurrence during root canal treatment. Int Endod J 2014;47:211-221. 